\title{
Attitudes toward the government helping blacks: The South versus the rest of the nation
}

\author{
HENRY B. SIRGO and RUSSELL EISENMAN \\ McNeese State University, Lake Charles, Louisiana
}

\begin{abstract}
Data on racial attitudes are studied, specifically on whether or not the government should help blacks. A survey was made of a national representative sample of 880 people who voted in the 1988 national elections. The results show the South to be different from the rest of the nation, with the South having both more people against government help of blacks but also more people favoring government help of blacks. The other regions tend to be neutral on the issue, but lean toward the no-help end of the scale. Thus, the South is unlike other regions, having a bipolar distribution on the issue of government help for blacks. This is true for both black and white Southerners. However, black Southerners were somewhat different from blacks outside the South.
\end{abstract}

The present study looks at the attitude of whether or not the government should help blacks, and considers the different regions of the United States and also the South versus all the different regions combined. The South may be different from the rest of the nation, at least in some instances (Eisenman, 1993b). Racial attitudes appear to be extremely important, especially in determining voting behavior. According to Carmines and Stimson $(1980,1989)$, race is the only issue to have arisen since the Roosevelt New Deal that has had a major effect on voting behavior in national elections. This view goes counter to the position of Ray (1984), who maintains that racial attitudes do not necessarily affect behavior. Ray cites the work of La Pierre (1934) and himself (Ray, 1971, 1976) to argue that racial attitudes are often unrelated to discriminatory behavior. This seems a surprising position, inconsistent with more recent work showing a link between holding conservative beliefs on the one hand and having racially discriminatory beliefs-for example, that minorities should not have equality of opportunity or that the government is too helpful to minorities (Eisenman, 199lb; Eisenman \& Sirgo, 1991; Sirgo \& Eisenman, 1990). That is, conservatives have been found to hold certain beliefs about social and political issues, including race, and they also may believe either in discrimination against people on the basis of race, or at least that minorities get too much help from the government. While not all conservatives have to fit this profile, the above-mentioned studies did support

\footnotetext{
The authors gratefully acknowledge funding by the Shearman Research Initiative Fund. The data utilized in this study were made possible by the Interuniversity Consortium for Political and Social Research. Neither the original collectors of the data nor the Consortium bear any responsibility for the analysis or the interpretations presented here. For correspondence or reprint requests, the addresses of the authors are: $\mathrm{H}$. B. Sirgo, Department of Social Sciences, McNeese State University, Lake Charles, LA 70609-2335, and R. Eisenman, Department of Psychology, McNeese State University, Lake Charles, LA 70609-1895.
}

this result, which would suggest that there is a relationship between conservative attitudes and discrimination. Eisenman and Sirgo (1991) found a significant tendency for conservatives to be Republicans and liberals to be Democrats.

Blacks may be seen as deviant (Eisenman, 1991a) and therefore looked down upon, perhaps especially by Southerners, given the history of slavery, the Civil War, and the Reconstruction era. As an example of apparent antiblack attitudes in the South, consider that the whites in Louisiana showed a preference for David Duke in U.S. Senate and gubernatorial elections, despite his Ku Klux Klan and Nazi background, and apparently because of his antiblack views (Eisenman, 1992). The attitudes of students toward Duke predicted his white vote in the U.S. Senate election of October 1990 (Eisenman, 1992). Eisenman (1993a, 1993c) found similar results. However, Eisenman (1991b) found that college women who identified themselves as conservatives said that neither African-Americans nor women should be President of the United States. One would think that such women, if they vote or express themselves in other ways, would not be inclined to favor blacks or policies that would be helpful to blacks (or to women). This was a nationwide study, so such attitudes cannot be said to reflect Southern opinion. It may be that the South is not different from the rest of the nation in attitudes on a wide variety of issues.

The present study sampled voters throughout the United States to study their racial attitudes regarding whether the government should help blacks. This was related to the region of the nation, to see whether people in different regions have different attitudes, especially the South versus the rest of the nation. The South has traditionally been seen as conservative but there may be fewer differences between the South and other regions than people suppose. So a study was done of the attitudes of people in different regions of the nation, regarding whether or not the government should help blacks. If the traditional conservatism of the South is paramount, then peo- 
ple in the South should be opposed to governmental help for blacks.

\section{METHOD}

\section{Subjects}

A nation-wide survey sample of registered voters in the 1988 national elections for the U.S. Senate, the U.S. House of Representatives, and the Presidency was carried out by the Institute for Survey Research, University of Michigan, as part of a larger survey of voters. This was a representative sample, to fit the demographic characteristics of 1988 voters. Respondents were surveyed at their households and a $71 \%$ response rate was achieved. The sample size for the data reported comprised 880 registered voters surveyed. The sampling was based on U.S. Census districts, and included all of the United States except Alaska and Hawaii. To be included, a subject had to be at least 18 years of age and a United States citizen on or before November 8, 1988. People living on military reservations were excluded.

\section{Definition of Regions}

United States Census Bureau definitions were used to define the region. Thus, the South was defined as all 11 states of the old Confederacy plus Delaware, the District of Columbia, Kentucky, Maryland, Oklahoma, and West Virginia. In total, then, the South was defined as the states of Alabama, Arkansas, Delaware, the District of Columbia, Florida, Georgia, Kentucky, Louisiana, Maryland, Mississippi, North Carolina, Oklahoma, South Carolina, Tennessee, Texas, Virginia, and West Virginia.

The Northeast region was defined as the states of Connecticut, Maine, Massachusetts, New Hampshire, New Jersey, New York, Pennsylvania, Rhode Island, and Vermont.

The North Central region was defined as the states of Illinois, Indiana, Iowa, Kansas, Michigan, Minnesota, Missouri, Nebraska, North Dakota, Ohio, South Dakota, and Wisconsin.

The West region was defined as the states of Alaska, Arizona, California, Colorado, Hawaii, Idaho, Montana, Nevada, New Mexico, Oregon, Utah, Washington, and Wyoming.

\section{Procedure}

The interviewees were asked whether the government should help blacks, and their answers were rated on a 1- to 7-point scale by trained raters, ranging from a score of 1 for saying, "The government should help blacks," to a score of 7 for saying, "Blacks should help themselves."

Table 1

Regions of the United States: Number of People Believing that the Government Should Help Blacks

\begin{tabular}{lccccccc}
\hline & \multicolumn{7}{c}{ Scale } \\
\cline { 2 - 8 } \multicolumn{1}{c}{ Region } & 1 & 2 & 3 & 4 & 5 & 6 & 7 \\
\hline Northeast & 12 & 7 & 13 & 49 & 27 & 15 & 29 \\
North Central & 13 & 8 & 21 & 62 & 39 & 35 & 61 \\
South & 38 & 18 & 22 & 50 & 54 & 53 & 84 \\
West & 10 & 11 & 26 & 55 & 16 & 28 & 24 \\
\hline
\end{tabular}

Note-1 = government should help blacks, 7 = blacks should help themselves $\left[\chi^{2}(18)=55.71, p=.0000\right]$.

Table 2

The South Versus the Rest of the Nation: Number of People Believing that the Government Should Help Blacks

\begin{tabular}{lccccccc}
\hline & \multicolumn{7}{c}{ Scale } \\
\cline { 2 - 8 } \multicolumn{1}{c}{ Region } & 1 & 2 & 3 & 4 & 5 & 6 & 7 \\
\hline South & 38 & 18 & 22 & 50 & 54 & 53 & 84 \\
Rest of the nation & 35 & 26 & 60 & 166 & 82 & 78 & 114 \\
\hline
\end{tabular}

Note-1 = government should help blacks, 7 = blacks should help themselves $\left[\chi^{2}(6)=32.47, p=.0000\right]$.
Table 3

The South Versus the Rest of the Nation: Number of Whites Believing that the Government Should Help Blacks

\begin{tabular}{lccccccc}
\hline & \multicolumn{7}{c}{ Scale } \\
\cline { 2 - 8 } \multicolumn{1}{c}{ Region } & 1 & 2 & 3 & 4 & 5 & 6 & \multicolumn{1}{c}{} \\
\hline South & 16 & 12 & 17 & 35 & 44 & 42 & 75 \\
Rest of the nation & 14 & 18 & 52 & 147 & 76 & 72 & 109 \\
\hline
\end{tabular}

Note-1 = government should help blacks, 7 = blacks should help themselves $\left[\chi^{2}(6)=30.54, p=.0000\right]$.

Table 4

The South Versus the Rest of the Nation: Number of Blacks Believing that the Government Should Help Blacks

\begin{tabular}{lccccccc}
\hline & \multicolumn{7}{c}{ Scale } \\
\cline { 2 - 8 } \multicolumn{1}{c}{ Region } & 1 & 2 & 3 & 4 & 5 & 6 & 7 \\
\hline South & 17 & 5 & 4 & 14 & 7 & 10 & 8 \\
Rest of the nation & 17 & 5 & 3 & 14 & 5 & 4 & 2 \\
\hline
\end{tabular}

Note-1 = government should help blacks, 7 = blacks should help themselves $\left[\chi^{2}(6)=4.77, p=.5733\right]$.

\section{RESULTS}

The results are summarized in Tables 1 and 2. Table 1 is on whether or not the government should help blacks by region of the nation, and Table 2 shows the South versus all the other regions collapsed. The South is both more and less supportive of help for blacks. That is, while the other regions of the nation are near the middle on this issue, and in fact slightly toward the side of not helping blacks, Southerners are much more likely to be toward one of the endpoints, saying either that the government should help blacks or that the government should not. Thus, the South has people at both ends of the scale while other parts of the nation are more neutral.

It seems possible that the data on Southerners wanting the government to help blacks are due to the fact that the Southern region of the United States has a large percentage of blacks. Thus, it could be that blacks tend to say that the government should help blacks, causing the South to be bipolar, with whites in the South, in contrast, saying the government should not help blacks. Tables 3 and 4 show that both whites and blacks in the South showed the bipolar responses. That is, for whites, Table 3 shows that $6.6 \%$ were at the most extreme response $(1$ on the 1-7 scale), advocating the government helping blacks, versus $2.9 \%$ for whites in the rest of the United States. For the second most extreme response (2 on the 1-7 scale) whites in the South represent $5.0 \%$ versus $3.7 \%$ in the rest of the nation. At the other end of the scale, where responses indicated opposition to the government helping blacks, whites in the South had $31.1 \%$ at the most extreme response, 7 on the 1-7 scale, versus $22.3 \%$ for whites in the rest of the nation. For the next closest opposition to the government helping blacks (6 on the 1-7 scale), there were $17.4 \%$ whites in the South so responding versus $14.8 \%$ in the rest of the nation. Thus, Table 3 shows that whites in the South are bipolar, with many more than in the rest of the United States saying the 
government should help blacks, and also many more saying the government should not help blacks.

Table 4 shows that blacks in the South are also bipolar in responding to the question of government helping or not helping blacks. Looking at all the black respondents in the South shows that many say that the government should help blacks, but many also say that the government should not help blacks. However, blacks outside of the South are stronger in saying that government should help blacks, and less likely to oppose government help of blacks, than are black Southerners. For example, while black Southerners show the bipolar result with $26.2 \%$ at Response 1 and $12.3 \%$ at Response 7 , in the rest of the nation the findings are that $34.0 \%$ of blacks were at $\mathrm{Re}$ sponse 1 and $4.0 \%$ at Response 7.

\section{DISCUSSION}

All regions except the South tend to be intermediate in the judgment of whether the government should help blacks or blacks should help themselves, although examination of each cell of the 1-7 ratings shows that more people are toward the 7 rating of blacks' helping themselves than toward the 1 rating of the government's helping blacks. The South is the region which most strongly says that blacks should help themselves, but is also the region which has a substantial percentage of people who believe in the government aiding blacks.

The results show that being from the South tends to go along with being against help for blacks for many, but there are also many other Southerners who favor the government helping blacks. Those who oppose government help of blacks may be demonstrating a conservative ideology. The conservative ideology seems to say that people should take care of themselves, and if blacks are not doing well, tough. This ideology could easily slip into a prejudiced blaming of the victim, by concluding that not only do blacks not deserve governmental help, but it is their fault for any problems they have. Such an outlook would ignore the social causes of black poverty in the United States, with all its attendant problems (Eisenman, 1991a, 1993a, 1993c). The liberal ideology seems to approve of government aid to those seen as needing help, in this case blacks.

The findings for the South are interesting, in that the South emerges as both the region most in favor of the government not helping blacks, but also the region which is most likely to have people who wish to help blacks. Thus, both extreme positions are in the South, with "extreme" not meant to have any negative connotation, since being different does not mean being bad, although people often take it that way (Eisenman, 1991a). Some Southerners are very opposed to government help for blacks, but others are very much in favor. People in the South appear to be capable of growing up and learning very conservative values that mitigate against the government interfering, even to help someone in need, or learning very liberal values, which call upon the government to provide support for people who are seen as needing help (Eisenman \& Sirgo, 1991; Sirgo \& Eisenman, 1990, 1993). Thus, the South comes across here as both more liberal and more conservative than the rest of the nation, which does not fit current stereotypes that say either that the South is more conservative than the rest of the nation, or that there is no difference between the South and the rest of the nation. Further study of this bipolar tendency in the South would seem warranted, to see if it appears in data on other issues.

Finally, it is interesting that both white and black Southerners showed the bipolar response. Thus, there are many whites in the South who favor government helping blacks, just as there are many whites in the South who do not. However, for blacks in the South, there are likewise many who believe that the government should help blacks, but surprisingly many who do not believe in such help. And, blacks in the rest of the United States are more in favor of the government helping blacks than are black Southerners. Growing up black in the South appears to lead to somewhat different attitudes than growing up black outside of the South.

\section{REFERENCES}

Carmines, E. G., \& Stimson, J. A. (1980). The racial reorientation of American politics. In J. C. Pierce \& J. L. Sullivan (Eds.), The electorate reconsidered (pp. 199-219). Beverly Hills, CA: Sage.

Carmines, E. G., \& Stimson, J. A. (1989). Issue evolution. Princeton, NJ: Princeton University Press.

EISEnman, R. (1991a). From crime to creativity: Psychological and social factors in deviance. Dubuque, IA: Kendall/Hunt.

EISENMAN, R. (1991b). Gender and racial prejudice of conservative college women. Psychological Reports, 68, 450.

EISENMAN, R. (1992). Creativity, social and political attitudes, and liking or disliking David Duke. Bulletin of the Psychonomic Society, 30, 19-22.

EISENMAN, R. (1993a). Contemporary social issues: Drugs, crime, creativity, and education. Ashland, $\mathrm{OH}$ : BookMasters.

Eisenman, R. (1993b). Professor Anita Hill versus Judge Clarence Thomas: The view of students at a Southern university. Bulletin of the Psychonomic Society, 31, 179-180.

Eisenman, R. (1993c). Student attitudes toward David Duke before and after seeing the film "Who is David Duke?' Bulletin of the Psychonomic Society, 31, 37-38.

EISENMAN, R., \& SiRGo, H. B. (1991). Liberals versus conservatives: Personality, child-rearing attitudes, and birth order/sex differences. Bulletin of the Psychonomic Society, 29, 240-242.

LAPIERRE, R. (1934). Attitudes and actions. Social Forces, 13, 230-237.

RAY, J. J. (1971). Ethnocentrism: Attitudes and behavior. Australian Quarterly, 43, 89-97.

RAY, J. J. (1976). Do authoritarians hold authoritarian attitudes? $\mathrm{Hu}$ man Relations, 29, 307-325.

RAY, J. J. (1984). Half of all racists are left wing. Political Psychology, 5, 227-235.

SirGo, H. B., \& Eisenman, R. (1990). Perception of governmental fairness by liberals and conservatives. Psychological Reports, 67, 1331-1334.

Sirgo, H. B., \& EISEnMan, R. (1993). Liberals versus conservatives: Are attitudes toward government related to experiences with government? Bulletin of the Psychonomic Society, 31, 155-157.

(Manuscript received May 11, 1993.) 